\title{
Effects of $\mathrm{Zn}^{2+}$ and $\mathrm{H}^{+}$Associations with Naphthalene Diimide Electrodes for Aqueous Zn-ion Batteries
}

Moony Na1,2, Yusik Oh,1,2 and Hye Ryung Byon 1,2,*

${ }^{1}$ Department of Chemistry, Korea Advanced Institute of Science and Technology (KAIST), 291 Daehak-ro, Yuseong-gu, Daejeon 34141, Republic of Korea

${ }^{2}$ Advanced Battery Center, KAIST Institute for NanoCentury, 291 Daehak-ro, Yuseong-gu, Daejeon 34141, Republic of Korea

E-mail: hrbyonekaist.ac.kr 
(a)
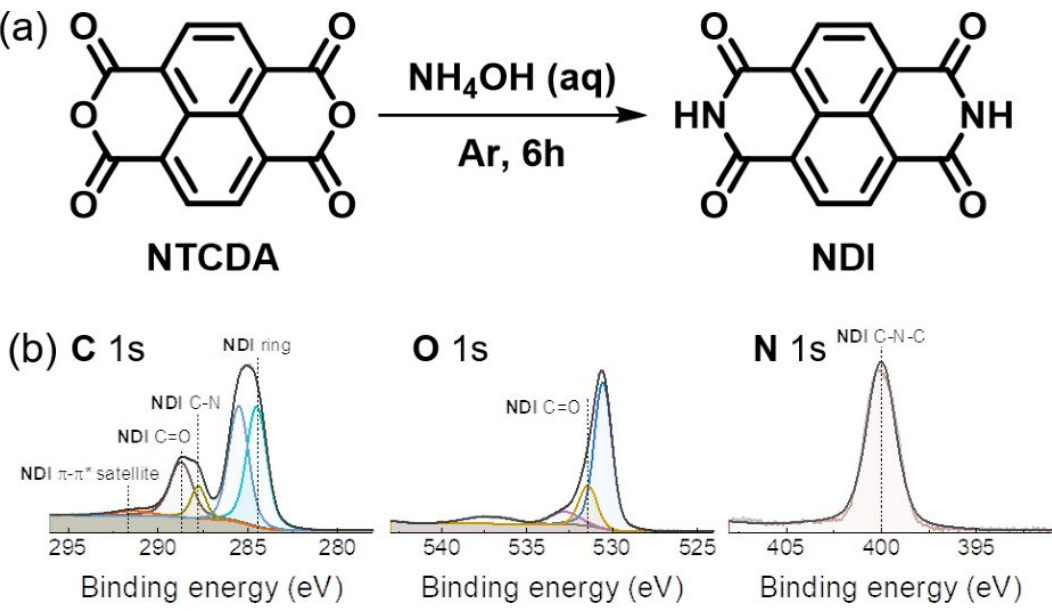

Figure s1. Synthesis and XPS characterization of NDI. (a) Schematic illustrations for the NDI synthetic process from a precursor of NTCDA. (b) XPS of NDI powder with $\mathrm{C} 1 \mathrm{~s}, \mathrm{O}$ 1s, and $\mathrm{N}$ 1s binding energy (BE) regions.

(a)

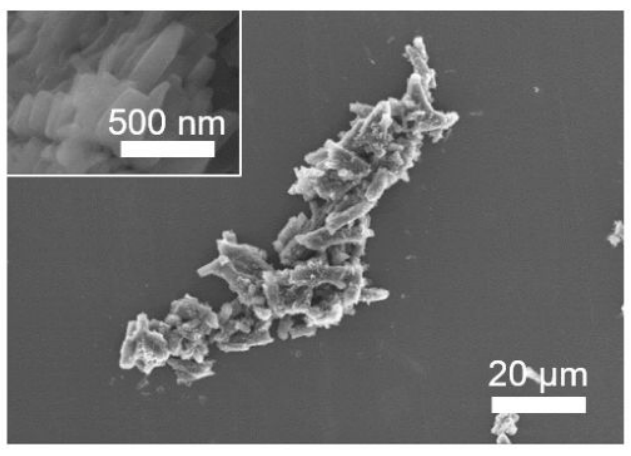

(b)

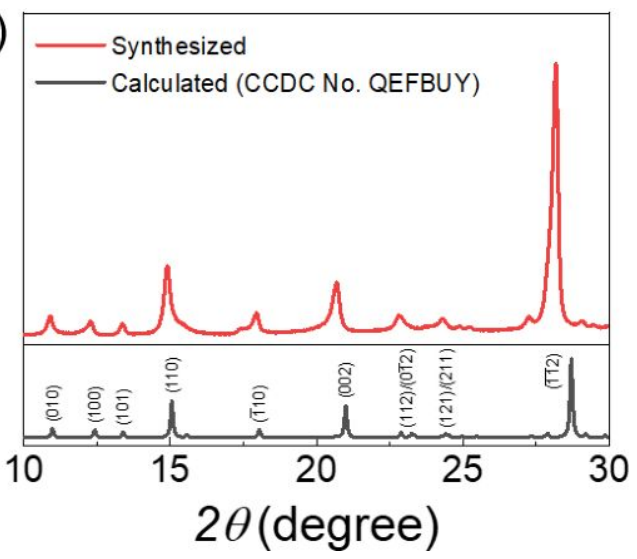

Figure S2. SEM and XRD analyses of as-synthesized NDI powders. (a) SEM images of polyhedral NDI particle. The inset image is the highmagnification image. (b) XRD pattern of as-prepared NDI powder (red) and the simulation result of triclinic structure (black). 

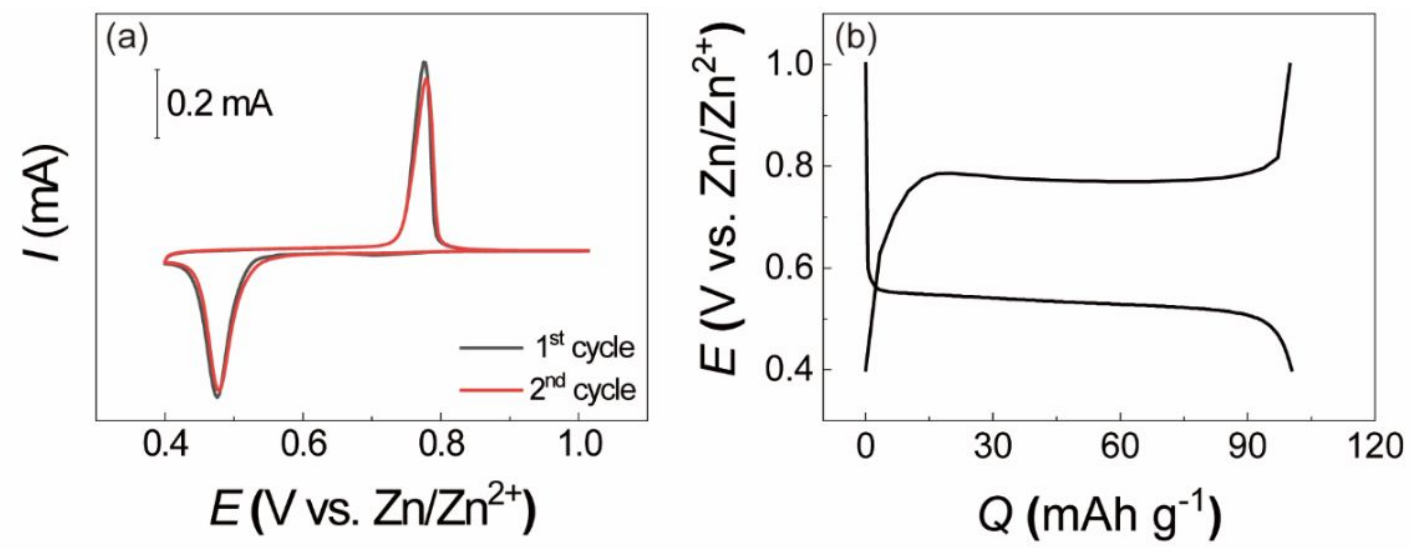

Figure s3. Identification of $\mathbf{A}_{1}$ corresponding to $\mathbf{C}_{1}$ events, defined by a cutoff potential at $0.4 \mathrm{~V}$ in $\mathrm{Zn}$-NDI cells including $1 \mathrm{M} \mathrm{ZnSO}_{4}$ (aq) . (a) First and second CV cycles of the NDI electrode at a scanning rate of $0.2 \mathrm{mV} \mathrm{s}^{-1}$. The total charge ratios used for $\mathbf{A}_{1}$ relative to $\mathbf{C}_{\mathbf{1}}\left(\mathbf{A}_{1} / \mathbf{C}_{\mathbf{1}}\right)$ were estimated to 0.95 and 0.93 for the first and second cycles, respectively. (b) Galvanostatic profile at a C/5 rate (equal to $40.2 \mathrm{mAh}$ $\left.g_{\mathrm{NDI}}{ }^{-1}\right)$ for the first cycle.
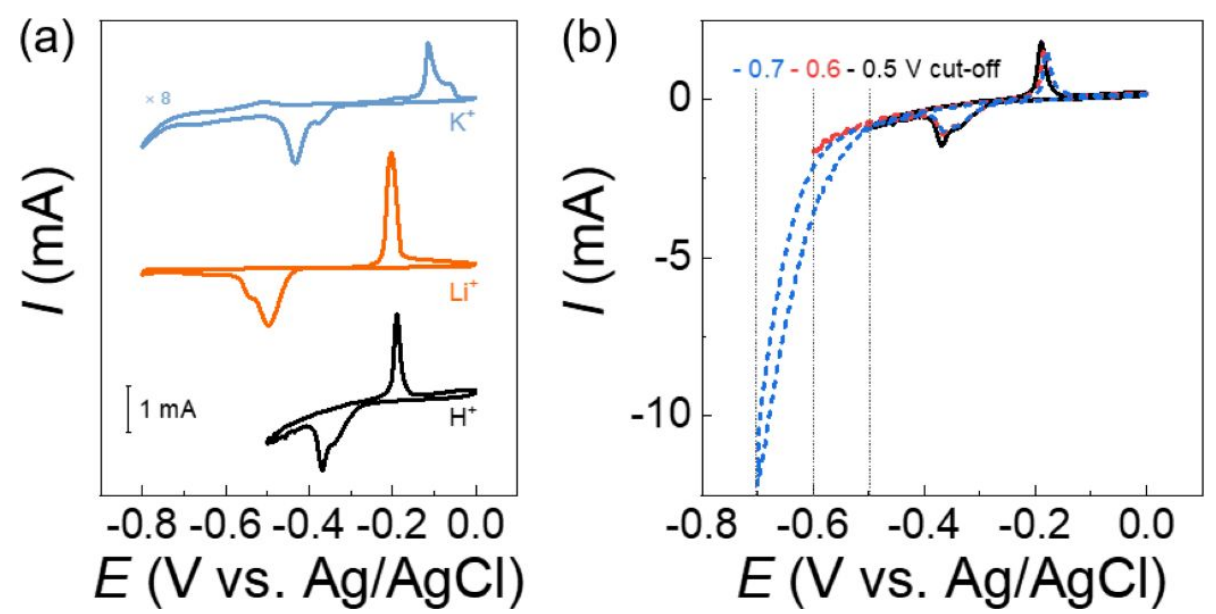

Figure S4. CV profiles of NDI electrodes with (a) 1 M LiOTf(aq) and 1 M NaOTf(aq) compared to 1 M HOTf(aq), and (b) 1 M HOTf(aq) with different cut-off potentials, $-0.5 \mathrm{~V}$ (black), $-0.6 \mathrm{~V}$ (red), and $-0.7 \mathrm{~V}$ (dashed blue line). The severe hydrogen evolution reaction (HER) appeared below 
$-0.5 \mathrm{~V}$ in the strongly acidic solution of $1 \mathrm{M}$ HOTf. The scan rates were $0.2 \mathrm{mV} \mathrm{s}^{-1}$. 
Table s1. Ionic mobility (u) at infinite dilution in aqueous solution at $25{ }^{\circ} \mathrm{C}$ and the measured potentials at $\mathbf{C}_{1}$ in 1 M aqueous electrolyte solution. ${ }^{1}$

\begin{tabular}{lll}
\hline & $\mathrm{u}\left(\mathrm{cm}^{2} \mathrm{sec}^{-1} \mathrm{~V}^{-1}\right)$ & $\mathrm{C}_{1}(\mathrm{~V} \mathrm{Vs} \cdot \mathrm{Ag} / \mathrm{AgCl})$ \\
\hline $\mathrm{H}^{+}$ & $3.625 \times 10^{-3}$ & $-0.34 /-0.37$ \\
$\mathrm{~K}^{+}$ & $7.62 \times 10^{-4}$ & $-0.40 /-0.43$ \\
$\mathrm{Li}^{+}$ & $4.01 \times 10^{-4}$ & $-0.50 /-0.54$ \\
$\mathrm{Zn}^{2+}$ & $5.47 \times 10^{-4}$ & -0.44 \\
\hline
\end{tabular}

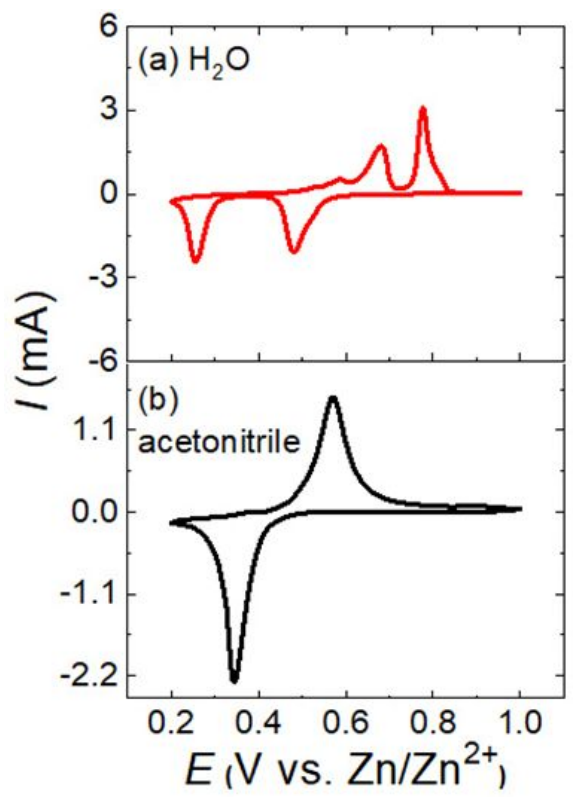

Figure s5. The $10^{\text {th }}$ cycle of CV curves in Zn-NDI cells with (a) $1 \mathrm{M}$ $\mathrm{Zn}(\mathrm{OTf})_{2}$ in aqueous solution and (b) 1 M Zn(OTf) 2 in acetonitrile electrolyte solutions. The scan rates were $0.2 \mathrm{mV} \mathrm{s}^{-1}$. 


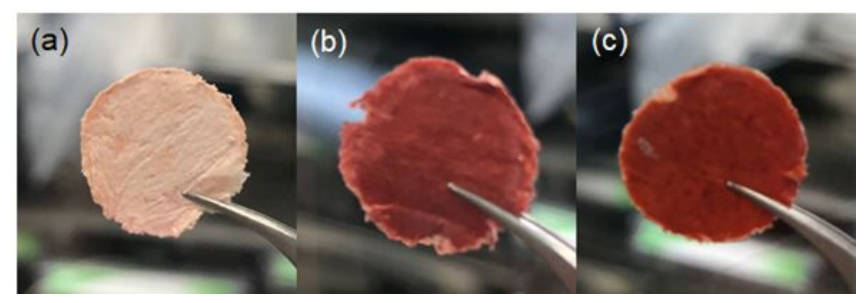

Figure s6. Digital photos of GF/C separators from non-aqueous Zn-NDI

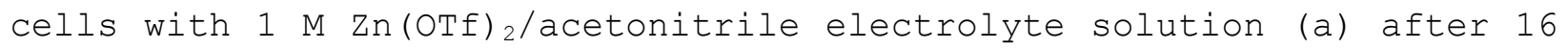
$h$ resting at $\mathrm{OCP}$, (b) after discharge, and (c) after charge. The deviation of the measured capacity ( $150 \mathrm{mAh} \mathrm{g}^{-1}$ NDI Figure 1d) from the theoretical one ( 201 $\left.\mathrm{mAh}^{-1} \mathrm{NDI}\right)$ might be due to dissolution of the NDI in the acetonitrile.
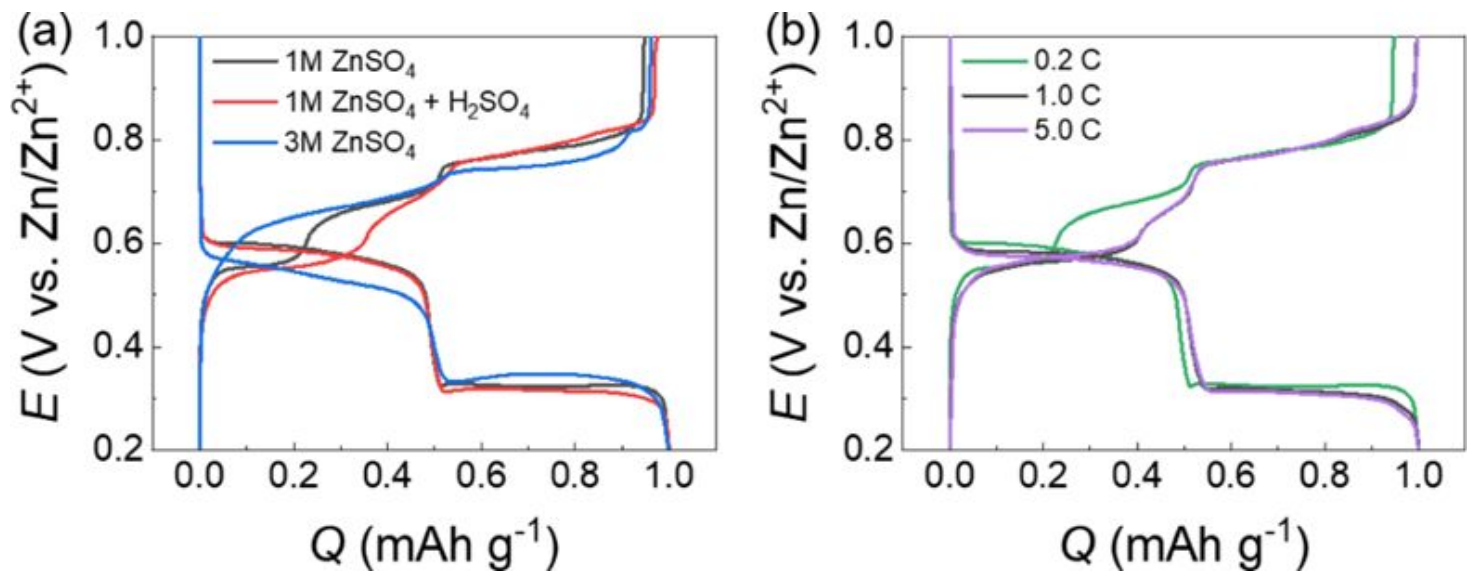

Figure s7. Comparative galvanostatic profile of Zn-NDI cells with different conditions. (a) Galvanostatic $1^{\text {st }}$ cycle at $0.2 \mathrm{C}$ with electrolyte solutions of $1 \mathrm{M} \mathrm{ZnSO}_{4}(\mathrm{aq})\left(\mathrm{pH}=5.2\right.$, black), $1 \mathrm{M} \mathrm{ZnSO}_{4}$ including $\mathrm{H}_{2} \mathrm{SO}_{4}(\mathrm{aq})$ ( $\mathrm{pH}=2.8$, red), and $3 \mathrm{M} \mathrm{ZnSO}_{4}(\mathrm{aq})$ ( $\mathrm{pH}=4.3$, blue). (b) Galvanostatic $1^{\text {st }}$ cycle with $1 \mathrm{M}_{\mathrm{ZnSO}_{4}(\mathrm{aq})}$ at $0.2 \mathrm{C}$ (green), $1 \mathrm{C}$ (black), and 5 C (violet). 


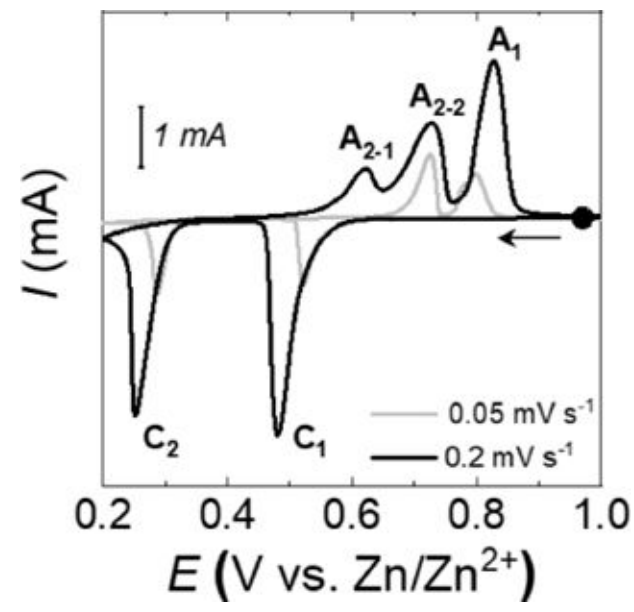

Figure s8. CV curves of $\mathrm{Zn}$-NDI cell with $1 \mathrm{M} \mathrm{ZnSO}_{4}$ (aq) at a scan rate of $0.05 \mathrm{mV} \mathrm{s}^{-1}$ (light gray) and $0.2 \mathrm{mV} \mathrm{s}^{-1}$ (black). The arrow indicates the scanning direction. 

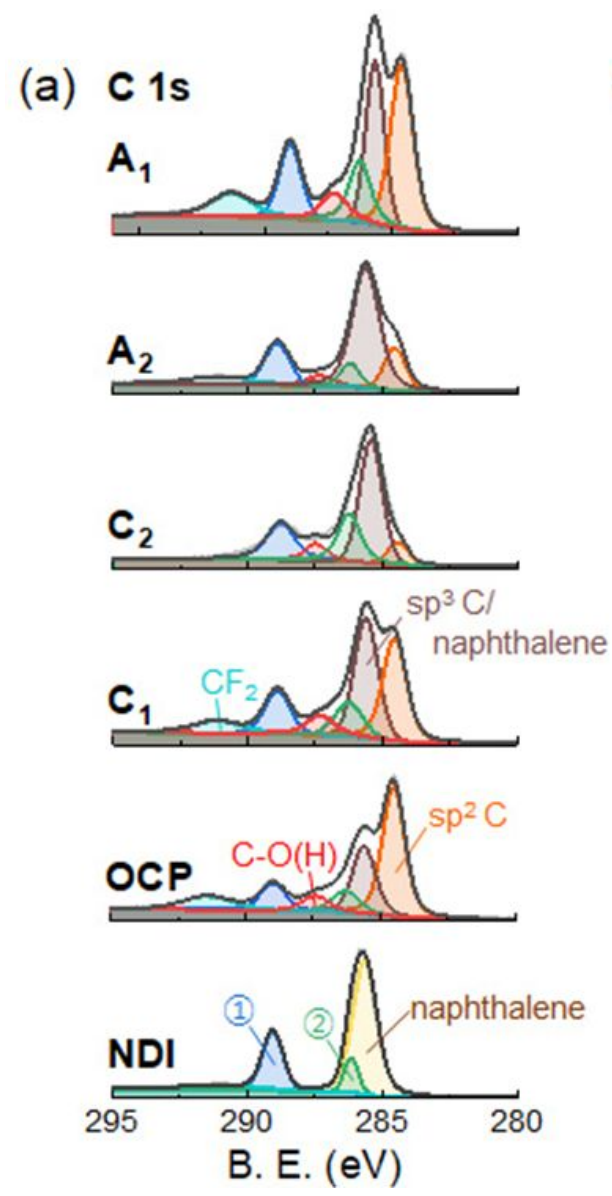

(b) Zn 2p
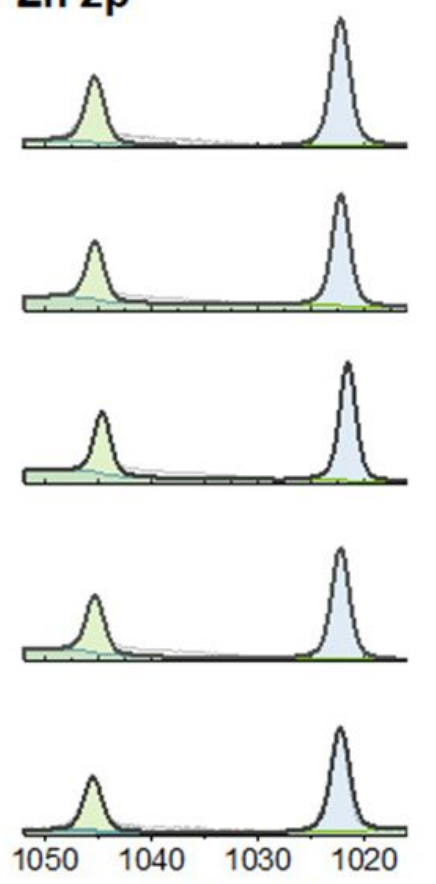

B. E. $(e V)$

Figure s9. XPS of (a) C 1s and (b) Zn 2p binding energy (BE) regions for NDI electrodes with open circuit potential (OCP) rest and different discharging and charging stages. The galvanostatic tests were conducted with $1 \mathrm{M} \mathrm{ZnSO}_{4}(\mathrm{aq})$ at $0.2 \mathrm{C}$, and the electrodes were thoroughly washed and dried in a vacuum oven.

As-synthesized NDI showed the polyaromatic carbon feature $(285.6 \mathrm{eV}$ in $C$ Is $\mathrm{BE}$ region), $\mathrm{C}=\mathrm{O}(289.0 \mathrm{eV})$ and $\mathrm{N}-\mathrm{C}=\mathrm{O}$ from the imide group (286.3 eV). ${ }^{2}$ The electrode with super $\mathrm{P}$ carbon and PVdF binder incorporated the $\mathrm{sp}^{2}-\mathrm{C}(284.5 \mathrm{eV}), \mathrm{sp}^{3}-\mathrm{C}$ hybridization $(285.6 \mathrm{eV}), \mathrm{C}-\mathrm{OH}(287.4 \mathrm{eV})$, and the $\mathrm{CF}_{2}$ species $(291.4 \mathrm{eV})$. $^{3}$ The invisible $\mathrm{CF}_{2}$ and small sp ${ }^{2} \mathrm{C}$ signals at the end of $\mathbf{C}_{\mathbf{2}}$ suggest the passivation of NDI electrode with byproduct, $\mathrm{ZnSO}_{4}\left[\mathrm{Zn}(\mathrm{OH})_{2}\right]_{3} \cdot 4 \mathrm{H}_{2} \mathrm{O}$. The $\mathrm{Zn}$ signals appear even after soaking the NDI electrode to the electrolyte solution and rested at OCP, possibly due 
to physically adsorbed $\mathrm{Zn}^{2+}$, although its amount is marginal (see Figure S13) .

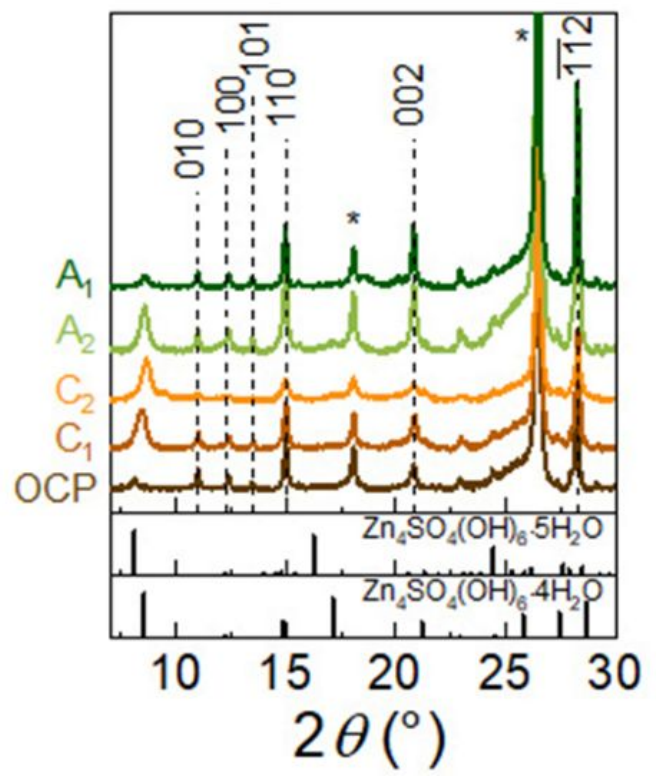

Figure s10. XRD patterns of NDI electrodes at different discharging and charging stages at $0.2 \mathrm{C}$ for the first cycle. All electrode samples were washed with DI water, followed by air drying. The bottoms are the references of $\mathrm{ZnSO}_{4}\left[\mathrm{Zn}(\mathrm{OH})_{2}\right]_{3} \cdot 4 \mathrm{H}_{2} \mathrm{O}$ and $\mathrm{ZnSO}_{4}\left[\mathrm{Zn}(\mathrm{OH})_{2}\right]_{3} \cdot 5 \mathrm{H}_{2} \mathrm{O}$. The asterisk mark indicates the carbon substrate. The 100 intensities (8 9०) of the zinc hydroxyl sulfate are similar after $\mathbf{C}_{\mathbf{1}}$ and $\mathbf{C}_{\mathbf{2}}$, suggesting co-formation of an amorphous structure during $\mathbf{C}_{2}$.

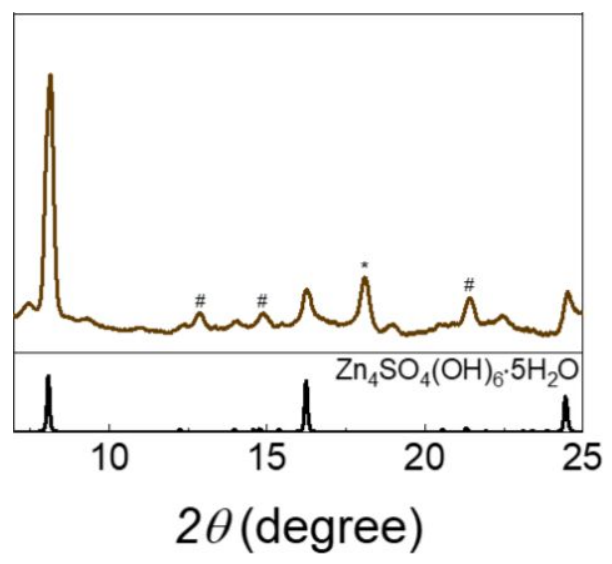


Figure s11. In situ XRD pattern of NDI electrode in the coin cell after the second discharge. There were no washing and drying processes. The bottoms are the references of $\mathrm{ZnSO}_{4}\left[\mathrm{Zn}(\mathrm{OH})_{2}\right]_{3} \cdot 5 \mathrm{H}_{2} \mathrm{O}$. The asterisk and hash marks indicate the carbon substrate and the NDI particle, respectively.

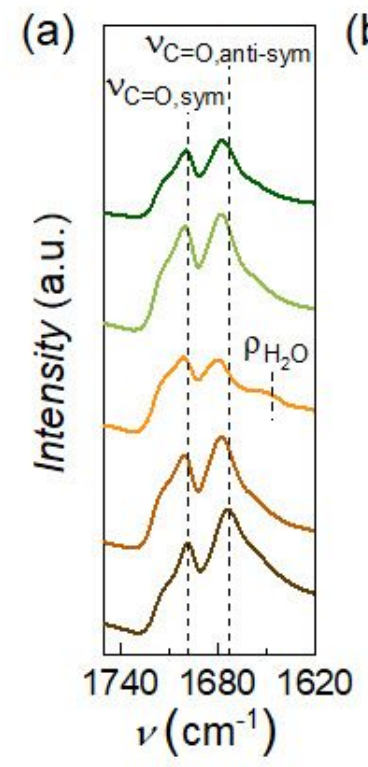

(b)

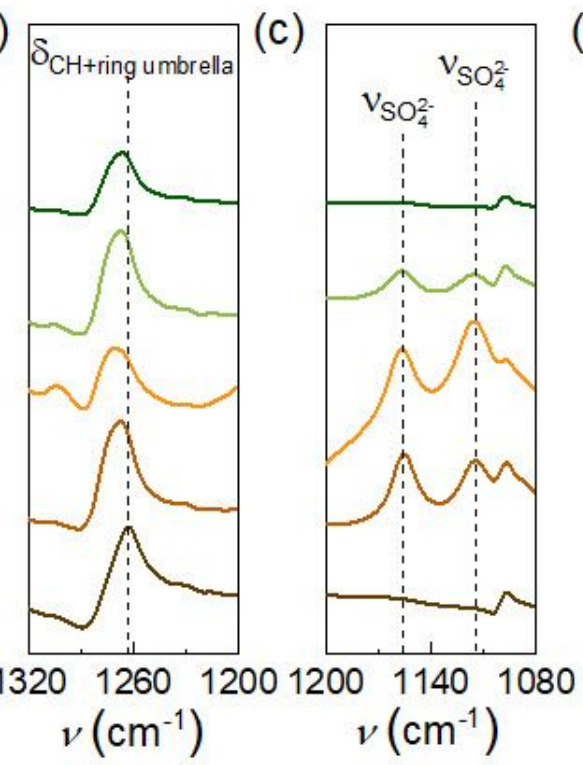

(d)

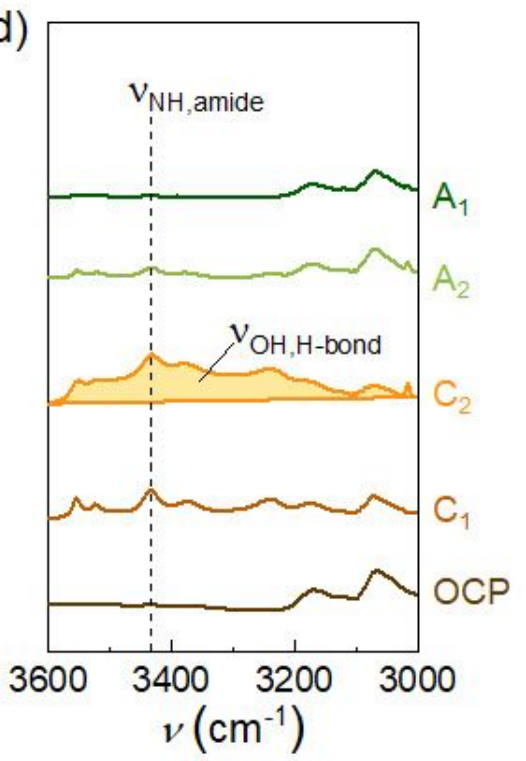

Figure S12. High magnification ATR-IR spectra of Figure 3a. (a) The antisymmetric $\mathrm{C}=0$ stretch signal $\left(\nu_{\mathrm{C}=0 \text {, anti-sym }}, 1673.8 \mathrm{~cm}^{-1}\right)$ was reduced, and became weaker than the symmetric mode $\left(\nu_{\mathrm{C}=0 \text {, sym }}, 1698.7 \mathrm{~cm}^{-1}\right)$ during $\mathbf{C}_{2}$. The frequency shifts of (a) the $v_{\mathrm{C}=0 \text {, anti-sym }}$ and (b) the bending mode of $\mathrm{CH}$ and NDI-ring umbrella ( $\delta_{\mathrm{CH}+\mathrm{ring}}$ umbrella, $1263.2 \mathrm{~cm}^{-1}$ ) were irreversible. We postulate the irreversible $\mathrm{H}^{+}$addition in part to NDI electrode. The remaining byproduct also supports incomplete $\mathrm{H}^{+}$extraction at the end of charge. (c) The $\mathrm{SO}_{4}{ }^{2-}$ vibrations arising from $\mathrm{ZnSO}_{4}\left[\mathrm{Zn}(\mathrm{OH})_{2}\right]_{3} \cdot 4 \mathrm{H}_{2} \mathrm{O}$. (d) The broad IR band in $3100 \sim 3600 \mathrm{~cm}^{-1}$. Along with the appearance of $\rho_{\mathrm{H} 20 \text {, scissor }}$ (1646.2 $\mathrm{cm}^{-1}$ ) in (a) at the end of $\mathbf{C}_{\mathbf{2}}$, the presence of $\mathrm{H}_{2} \mathrm{O}$ was demonstrated from both inside of the NDI electrode and from $\mathrm{ZnSO}_{4}\left[\mathrm{Zn}(\mathrm{OH})_{2}\right]_{3} \cdot 5 \mathrm{H}_{2} \mathrm{O} \cdot{ }^{4}$ The small $0-\mathrm{H}$ stretches emerging at $\sim 3372$ and $\sim 3523 \mathrm{~cm}^{-1}$ are associated with the lattice water in the $\mathrm{ZnSO}_{4}\left[\mathrm{Zn}(\mathrm{OH})_{2}\right]_{3} \cdot 4 \mathrm{H}_{2} \mathrm{O} .5$ The secondary amine (N-H) vibration from the amide group is invisible from the as-prepared electrode, caused by strong intermolecular hydrogen bonds of $\mathrm{C}=\mathrm{O} \cdot \mathrm{HN}$ among the NDI molecules. However, this $v_{\mathrm{N}-\mathrm{H}}$ band emerged at $3431.4 \mathrm{~cm}^{-1}$ 
during discharge, referred to the weakly linked $\mathrm{N}-\mathrm{H}$ stretching band, $v_{\mathrm{N}-}$ H, weakly linked $\left(3348 \mathrm{~cm}^{-1}\right)$, and the $\mathrm{N}-\mathrm{H}$ band from single NDI molecule, $V_{\mathrm{N}-\mathrm{H} \text {, free }}$ (3476 $\left.\mathrm{cm}^{-1}\right) \cdot{ }^{6}$ It implies variable intermolecular interactions of NDI particle through the electron-transfer process and the ion-association process.

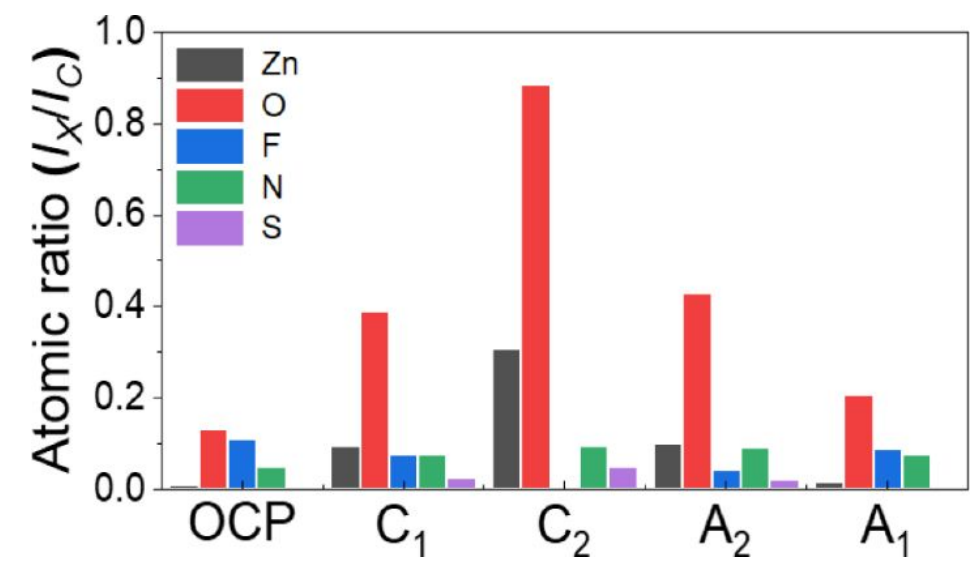

Figure s13. Atomic of $\mathrm{Zn}, \mathrm{O}, \mathrm{F}, \mathrm{N}, \mathrm{S}$ relative to $\mathrm{C}$ with different discharging and charging stages, acquired from XPS analysis. The increased $O$ atomic $\frac{\circ}{0}$ is attributed to formation of the $\mathrm{ZnSO}_{4}\left[\mathrm{Zn}(\mathrm{OH})_{2}\right]_{3}$. $4 \mathrm{H}_{2} \mathrm{O}$.

Table s2. Full width at half maximum (FWHM) of XRD reflections at different discharging and charging stages at $0.2 \mathrm{C}$ for the 1 st cycle.

\begin{tabular}{llllll}
\hline & OCP & $\mathbf{C}_{1}$ & $\mathbf{C}_{2}$ & $\mathbf{A}_{2}$ & $\mathbf{A}_{1}$ \\
\hline 010 & 0.13 & 0.16 & 0.25 & 0.15 & 0.13 \\
100 & 0.15 & 0.22 & 0.35 & 0.27 & 0.13
\end{tabular}




\begin{tabular}{llllll}
101 & 0.12 & 0.17 & $\mathrm{~N} / \mathrm{A}$ & 0.14 & 0.14 \\
110 & 0.18 & 0.20 & 0.36 & 0.22 & 0.16 \\
002 & 0.26 & 0.29 & 0.87 & 0.26 & 0.18 \\
112 & 0.17 & 0.19 & 0.33 & 0.18 & 0.14 \\
\hline
\end{tabular}
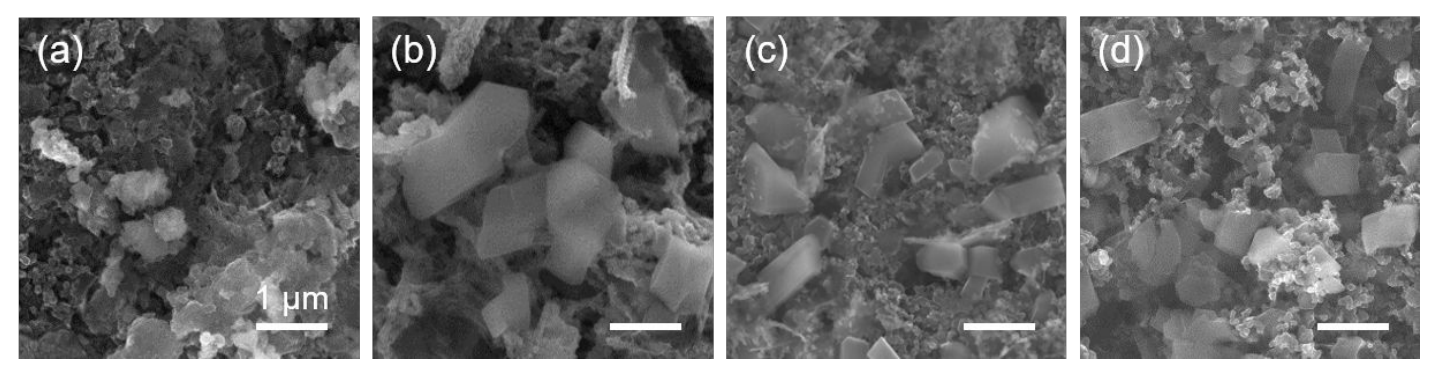

Figure 514. SEM images of NDI electrodes after (a) $\mathbf{C}_{1}$, (b) $\mathbf{C}_{2}$, (c) $\mathbf{A}_{\mathbf{2}}$, and (d) $\mathbf{A}_{1}$, respectively. All scale bars indicate 1 m. The significant increase of the NDI particular size appears when $\mathbf{C}_{\boldsymbol{1}}$ and $\mathbf{C}_{\mathbf{2}}$ are compared. Then the NDI particles become moderately smaller after $\mathbf{A}_{2}$, whereas there is a marginal change after $\mathbf{A}_{1}$. We note that the granular structures are observed in after $\mathbf{C}_{2}$ only along with the enlarged NDI particles, implying the significant formation of amorphous byproduct, zinc hydroxy sulfate.

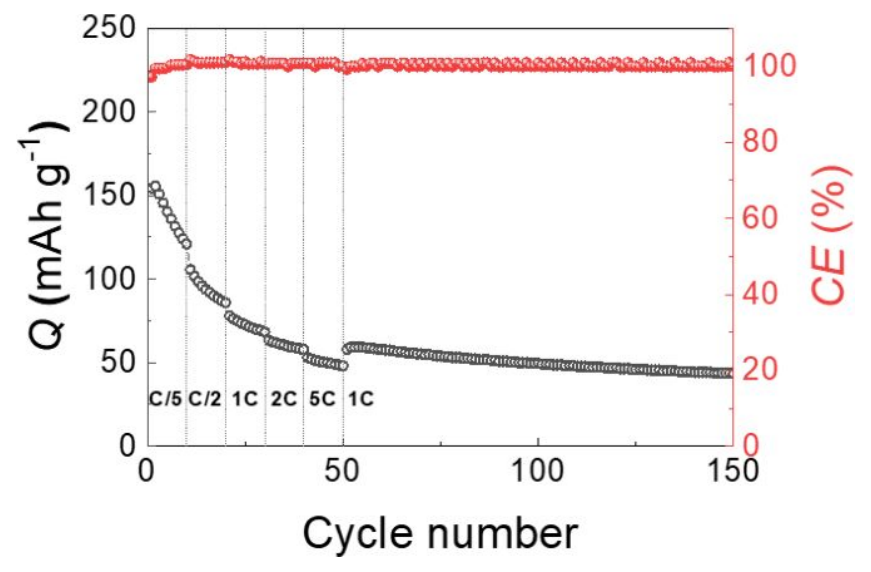


Figure s15. Rate capabilities of Zn-NDI cells with 1 M Zn (OTf) 2 /acetonitrile electrolyte solution from $0.2 \mathrm{C}$ to $5 \mathrm{C}$. The severe capacity fading arose from dissolution of NDI molecules in the acetonitrile.

(a)

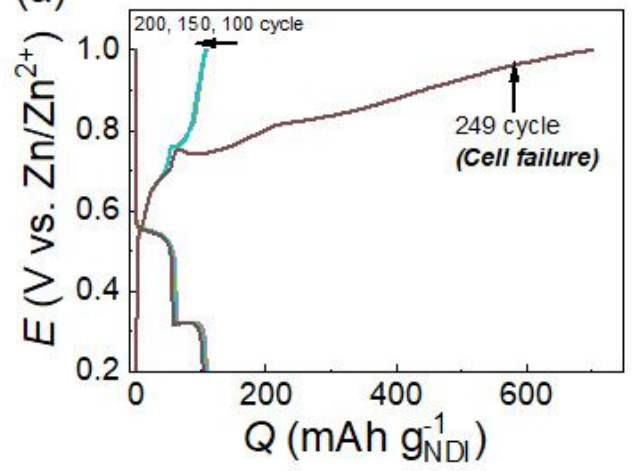

(b)

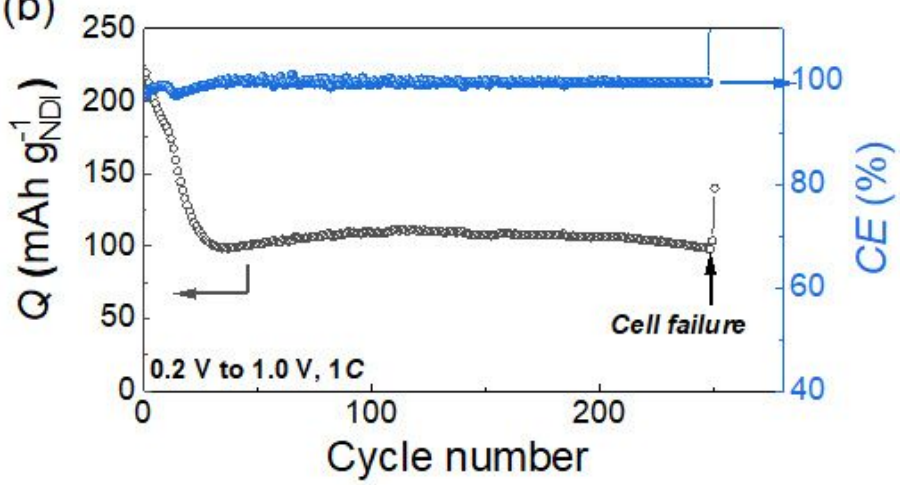

Figure S16. Galvanostatic cycling performance of $\mathrm{Zn}$-NDI with $1 \mathrm{M} \mathrm{ZnSO}_{4}(\mathrm{aq})$ in the potential range of $0.2 \mathrm{~V}-1.0 \mathrm{~V}$ Vs. $\mathrm{Zn} / \mathrm{Zn}^{2+}$ (from $\mathbf{C}_{1}, \mathbf{C}_{\mathbf{2}}$ to $\mathbf{A}_{2}, \mathbf{A}_{1}$ full stages). The current rate was $1 \mathrm{C}$. The cell was failed at the $249^{\text {th }}$ cycle. (a) Galvanostatic profiles at 100, 150, 200, and 249th cycles. (b) Cycling performance and Coulombic efficiency (CE) at $1 \mathrm{C}$. 


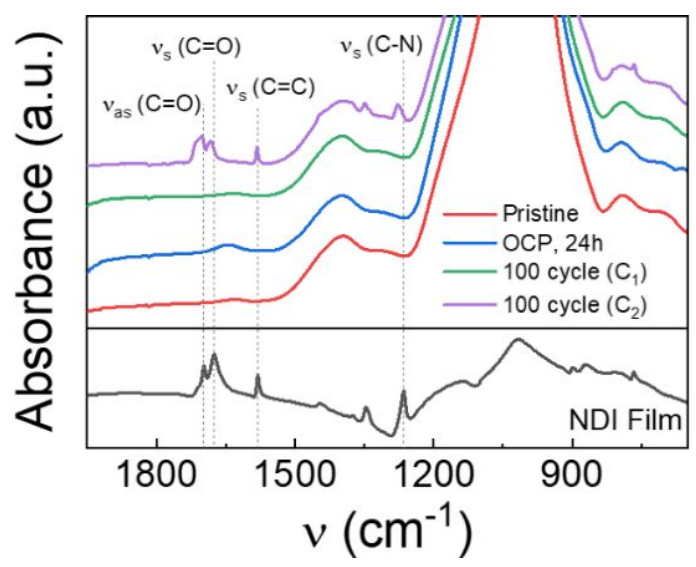

Figure s17. ATR-IR spectra of GF/C separator after 100 cycles at 5 C with $1 \mathrm{M} \mathrm{ZnSO}_{4}(\mathrm{aq})$. The pristine separator (red) and the separator at OCP (blue) did not show any NDI IR signal. After 100 cycles with the cut-off potential range by $\mathbf{C}_{1}$ (green, 0.4-1.0 V), there is no evidence of NDI deposition, whereas the separator after 100 cycles by $\mathbf{c}_{\mathbf{2}}$ reaction (violet, 0.2-1.0 V) showed the NDI vibration features, demonstrating solvation of the NDI molecules. The bottom graph is the IR reference of NDI film.

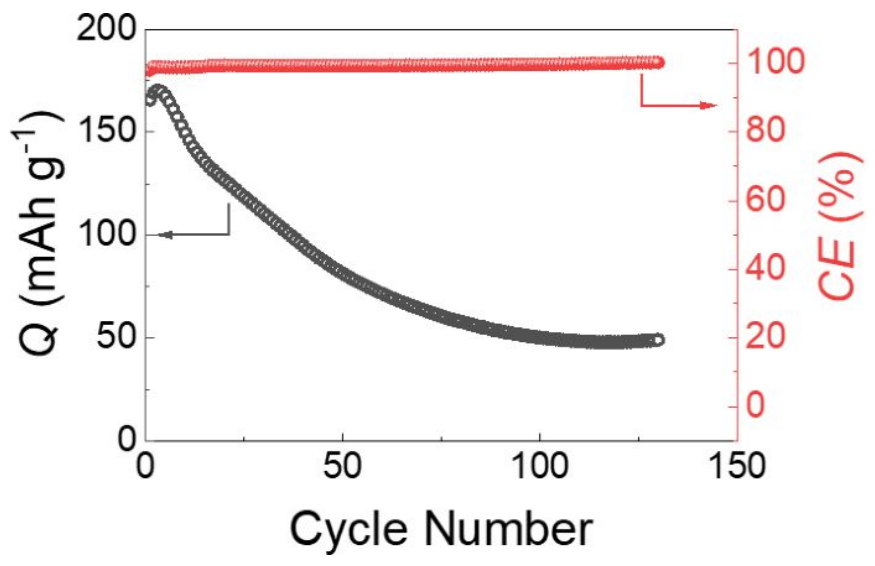

Figure s18. Galvanostatic cycling performance and CE of Zn-NDI cells with $3 \mathrm{M} \mathrm{ZnSO}_{4}(\mathrm{aq})$. The cycle was conducted at $1 \mathrm{C}$ in the full stages in $0.2-1.0 \mathrm{~V}$. 


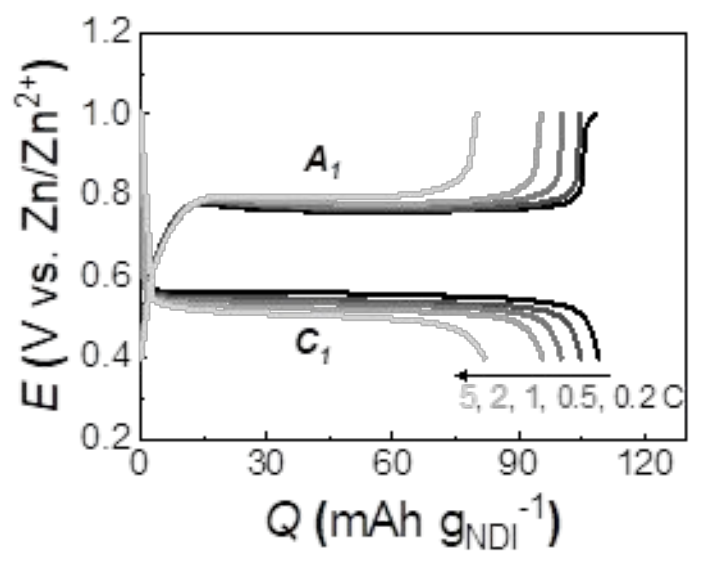

Figure s19. Galvanostatic voltage profiles with increasing current rate from $0.2 \mathrm{C}$ to $5 \mathrm{C}$ with $1 \mathrm{M} \mathrm{ZnSO}_{4}(\mathrm{aq})$. The curves were collected from the $3^{\text {rd }}$ cycle of each current rate.

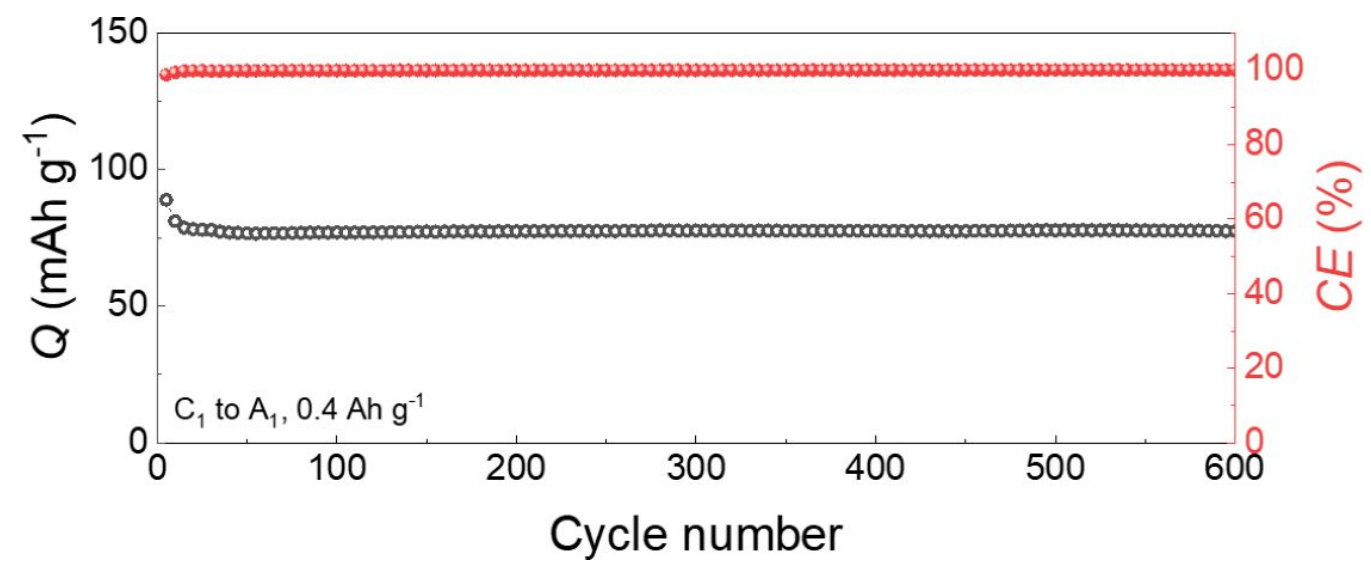

Figure s20. Galvanostatic cycling performance of Zn-NDI cells at 2 C. The electrolyte solution was $1 \mathrm{M}^{2} \mathrm{nSO}_{4}$ (aq) and the potential was limited to $0.4-1.0 \mathrm{~V}$. 


\section{REFERENCES}

1. Atkins, P.; de Paula, J., Atkins' Physical Chemistry. OUP Oxford: 2010.

2. Ding, Y.; Zhang, F.; Xu, J.; Miao, Y.; Yang, Y.; Liu, X.; Xu, B., Synthesis of short-chain passivated carbon quantum dots as the light emitting layer towards electroluminescence. RSC Adv. 2017, 7 (46), 28754-28762.

3. Ferraria, A. M.; Lopes da Silva, J. D.; Botelho do Rego, A. M., XPS studies of directly fluorinated HDPE: problems and solutions. Polymer 2003, 44 (23), 7241-7249.

4. Stanimirova, T.; Kerestedjian, T.; Kirov, G., Dehydration and rehydration of $Z$ n-hydroxy sulfate minerals with interrupted decorated hydroxide sheets. Appl. Clay Sci. 2017, 135, 16-26.

5. Dash, D. C., Analytical Chemistry. PHI Learning: 2011.

6. Seydou, M.; Teyssandier, J.; Battaglini, N.; Kenfack, G. T.; Lang, P.; Tielens, F.; Maurel, F.; Diawara, B., Characterization of NTCDI supra-molecular networks on Au(111); combining STM, IR and DFT calculations. RSC AdV. 2014, 4 (49), $25698-25708$. 